\title{
A Study to Assess the Knowledge of Mothers of Preschoolers regarding Home Accidents and Their Prevention in a Selected Rural Community of Moradabad, UP
}

\author{
Neha John ${ }^{1}$ \\ ${ }^{1}$ Tutor, Rufaida College of Nursing, Jamia Hamdard. \\ DOI: https://doi.org/10.24321/2455.9318.201805
}

\begin{abstract}
A house is an exciting place for infants and small children, who love to explore but are not aware of the potential dangers. Life cannot be risk-free, but most household accidents can be prevented by utilizing a household safety list. The incidence of accidental injuries is increasing in India, especially home accidents, among children. The main causes of accidents at home are falls, fire, burns, drowning, suffocation, choking, poisoning, cuts, and lacerations with a large number happening in the living room but, however, the most serious ones happen in the kitchen. The mother should know about the home safety needs of under-five children because mothers are usually the caregivers, and who will be at home with the child. Therefore, the investigator felt the real need for assessing the knowledge of mothers of preschoolers on home accidents and their prevention. The research approach selected for the present study was quantitative research and the research design as descriptive survey design. The data collection tool was a structured interview schedule, and the technique used was interviewing. Sixty mothers of preschoolers were selected through purposive sampling technique and were interviewed to collect the data. Analysis of the data indicated that the majority (83\%) of mothers of preschoolers was having moderate knowledge followed by $12 \%$ mothers having adequate knowledge and only $5 \%$ had inadequate knowledge regarding home accidents and their prevention. It also showed a significant association between knowledge regarding home accidents and their prevention with employment status and educational level of mothers. Thus it can be concluded that most of the mothers of preschoolers have moderate knowledge regarding home accidents and their prevention.

Keywords: Home accidents, Knowledge, Mothers of preschoolers
\end{abstract}

\section{Introduction}

Home accidents are one of the leading causes of death. Home accident is an accident which takes place in the home or in its immediate surroundings. ${ }^{1}$ The main causes of accidents in the home are falls, fires and burns, suffocation, choking, poisoning, cuts, and lacerations. Accidents are one of the five leading causes of death in industrialized and developing countries. Injuries arising from home accidents are increasing community health problems. Also every year many children are injured or killed as a result of accidental poisoning, falls, burns, and bits. ${ }^{2}$
The loss of children's lives resulting from all injuries combined represents a staggering number of years of productive lives lost in the society. Childhood injuries lead to about 16,000 deaths each year and $70 \%$ of these are the result of unintentional injuries. ${ }^{3}$

The mother should know about home safety needs of under-five children because mothers are usually the caregivers, and who will be at home with the child. A study was conducted to assess mothers' knowledge and practice towards home accidents among children less than 6 years. The above study revealed that the incidence of home accidents was $50.3 \%$ and shows a high statistical

E-mail Id: nehajohn1812@gmail.com

Orcid Id: https://orcid.org/0000-0002-0653-2003

How to cite this article: John N. A Study to Assess the Knowledge of Mothers of Preschoolers regarding Home Accidents and Their Prevention in a Selected Rural Community of Moradabad, UP. Int J Nurs Midwif Res 2018; 5(1): 18-21. 
difference between mothers' knowledge and age and between mothers' knowledge and education. About threequarters $(74.5 \%)$ of mothers had incomplete knowledge regarding home accidents among their children. ${ }^{4}$

The investigator also believes that knowledge of mothers on home accidents and their prevention can significantly prevent or control the number of home accidents taking place in the society. Keeping this in mind, the investigator undertook this study.

\section{Materials and Methods}

The present study was aimed to assess the knowledge of mothers regarding home accidents and their prevention and to seek the association of knowledge with selected demographic variables of mothers; so a quantitative research approach was found appropriate and most suitable for the study and descriptive survey research design was adopted for the study.

The present study was conducted in the Lodhipur village of Moradabad district in Uttar Pradesh. The criteria for selection of setting were convenience and familiarity with the setting. The population for the present study comprised all the mothers of preschoolers residing in UP state. The sample of the present study comprised 60 mothers of preschoolers residing in Lodhipur village, UP, selected through purposive sampling technique. The sample size was calculated using the power formula.

The tool used to collect the data from the samples was a structured interview schedule. The structured interview schedule was administered to seek information on demographic data of the respondents and to collect data on level of knowledge of mothers regarding home accidents and their prevention. The reliability of tool was established using KR 20 and the tool was found to be reliable. The validity of tool was established by giving it to seven experts from the field of nursing and the tool was found to be valid.

The data was collected after obtaining ethical permission from the panchayat leaders of the village and consent was obtained from the mothers of preschoolers.

The data was analyzed using descriptive and analytical statistics. The demographic variables of the subjects were described using frequencies and percentages. The level of knowledge of mothers regarding home accidents and their prevention was assessed, using mean, median, and standard deviation, and analytical statistics were used to find the association of knowledge of mothers regarding home accidents with the selected demographic variables of mothers through chi-square test.

\section{Results}

\section{Section 1: Findings related to Demographic Data}

Table 1.Frequency and Percentage Distribution of Mothers of Preschoolers in Terms of Their Demographic Data

\begin{tabular}{|c|c|c|c|}
\hline \multicolumn{2}{|c|}{ Variables } & Frequency & Percentage (\%) \\
\hline \multirow{3}{*}{ Age } & 19-24 years & 12 & 20 \\
\hline & $25-30$ years & 24 & 40 \\
\hline & Above 30 years & 24 & 40 \\
\hline \multirow[t]{4}{*}{ Religion } & Hindu & 25 & 42 \\
\hline & Christian & 10 & 17 \\
\hline & Muslim & 20 & 33 \\
\hline & Others & 5 & 8 \\
\hline \multirow[t]{3}{*}{ Educational status } & Illiterate & 16 & 27 \\
\hline & Primary and secondary & 15 & 25 \\
\hline & Higher education and above & 29 & 48 \\
\hline \multirow[t]{3}{*}{ Number of children } & 1 & 7 & 12 \\
\hline & 2 & 15 & 25 \\
\hline & 2 or more & 38 & 63 \\
\hline \multirow[t]{3}{*}{ Type of house } & Kacha & 20 & 33 \\
\hline & Pakka & 15 & 25 \\
\hline & Semi-pakka & 25 & 42 \\
\hline \multirow[t]{2}{*}{ Employment } & Employed & 42 & 70 \\
\hline & Unemployed & 18 & 30 \\
\hline \multirow[t]{3}{*}{ Family monthly income } & Rs. below 5000 & 18 & 30 \\
\hline & Rs. $5000-10000$ & 30 & 50 \\
\hline & Above Rs. 10000 & 12 & 20 \\
\hline
\end{tabular}


Section 2: Findings related to Knowledge Scores of Mothers of Preschoolers

Table 2.Frequency and Percentage Distribution of Knowledge Scores of Mothers of Preschoolers

\begin{tabular}{|c|c|c|c|c|}
\hline S. No. & Categorization of Knowledge Score & Range of Score & \multicolumn{2}{|c|}{ Mothers of Preschoolers } \\
\cline { 3 - 5 } & & & Frequency & Percentage \\
\hline 1. & Adequate & $21-30$ & 7 & 12 \\
\hline 2. & Moderate & $11-20$ & 50 & 83 \\
\hline 3. & Inadequate & $0-10$ & 3 & 5 \\
\hline
\end{tabular}

Section 3: Findings related to Association between Knowledge Score and Selected Demographic Factors of Mothers of Preschoolers

Table 3.Association between Knowledge Scores and Selected Demographic Factors of Mothers of Preschoolers

\begin{tabular}{|c|c|c|c|c|c|c|}
\hline \multirow[t]{2}{*}{ S. No. } & \multirow{2}{*}{ Demographic Variable } & \multicolumn{3}{|c|}{ Knowledge Score } & \multirow{2}{*}{$\begin{array}{c}\text { Fisher Exact } \\
\text { Value }\end{array}$} & \multirow[t]{2}{*}{ p Value } \\
\hline & & Inadequate & Moderate & Adequate & & \\
\hline \multirow[t]{3}{*}{1.} & $19-24$ & 0 & 11 & 1 & \multirow[t]{3}{*}{0.8273} & \multirow[t]{3}{*}{0.934} \\
\hline & $25-30$ & 1 & 20 & 3 & & \\
\hline & $>30$ & 1 & 19 & 4 & & \\
\hline \multirow[t]{5}{*}{2.} & Religion & & & & & \\
\hline & Hindu & 1 & 21 & 3 & \multirow[t]{4}{*}{0.3429} & \multirow[t]{4}{*}{0.842} \\
\hline & Muslim & 0 & 9 & 1 & & \\
\hline & Christian & 1 & 16 & 3 & & \\
\hline & Others & 0 & 4 & 1 & & \\
\hline \multirow[t]{4}{*}{3.} & Educational status & & & & & \\
\hline & Illiterate & 0 & 14 & 2 & \multirow[t]{3}{*}{$0.14^{*}$} & \multirow[t]{3}{*}{0.042} \\
\hline & Primary \& secondary & 0 & 13 & 2 & & \\
\hline & Graduate & 2 & 23 & 4 & & \\
\hline \multirow[t]{4}{*}{4.} & Number of children & & & & & \\
\hline & 1 & 0 & 6 & 0 & \multirow[t]{3}{*}{3.329} & \multirow[t]{3}{*}{0.504} \\
\hline & 2 & 1 & 13 & 1 & & \\
\hline & More than 2 & 1 & 31 & 7 & & \\
\hline \multirow[t]{4}{*}{5.} & Type of house & & & & & \\
\hline & Kacha & 0 & 16 & 4 & \multirow[t]{4}{*}{1.504} & \multirow[t]{4}{*}{0.825} \\
\hline & Pakka & 1 & 13 & 1 & & \\
\hline & Semi-pakka & 1 & 21 & 3 & & \\
\hline \multirow[t]{3}{*}{6.} & Employment & & & & & \\
\hline & Employed & 2 & 37 & 3 & \multirow[t]{2}{*}{$4.642^{*}$} & \multirow[t]{2}{*}{0.031} \\
\hline & Unemployed & 0 & 13 & 5 & & \\
\hline \multirow[t]{4}{*}{7.} & Family monthly income & & & & & \\
\hline & $>5000$ & 0 & 30 & 2 & \multirow[t]{3}{*}{0.0099} & \multirow[t]{3}{*}{0.920} \\
\hline & $5000-10000$ & 2 & 15 & 1 & & \\
\hline & $>10000$ & 0 & 0 & 0 & & \\
\hline
\end{tabular}

*Significant at 0.05 level of significance

The data presented in Table 4 shows that there was a significant association between the knowledge score and the employment of the mothers of preschoolers and also between the knowledge score and educational status of the mothers.

\section{Discussion}

A study was conducted by Naglaa et al. ${ }^{5}$ to assess mothers' knowledge and practice towards home accidents among children under six years and to determine the prevalence 
rate of home accidents among children under six years. The results of the study show significant correlation between the mother's knowledge and age and between mother's knowledge and education. About three-quarters (74.5\%) of mothers had incomplete knowledge regarding home accidents among their children. The findings of the present study are consistent with the findings of this study which show majority of mothers of preschooler were having moderate knowledge on home hazards and their prevention and there is a significant association between the knowledge of mothers with their educational levels.

A study was conducted by Oladunjoye ${ }^{6}$ on the effect of mothers' education on prevention of home accidents among preschool children in Ilesa Metropolitan city. The study adopted survey method and data collection was through a structured questionnaire. 187 nursing mothers were interviewed. The data collected was analyzed, using both descriptive and inferential statistics. Findings revealed that there is a significant correlation between mothers' knowledge and their educational levels indicating that the level of education has significant impact on the level of knowledge regarding the causes and prevention of home accidents among preschool children. Furthermore, the result shows a significant correlation between mothers' age and their level of knowledge. The findings of the present study are consistent with the findings of this study which also show a significant association between knowledge of mothers on home accidents with their educational level. ${ }^{6}$

\section{Conclusion}

The major conclusions drawn on the basis of the findings of the study were that the majority of mothers of preschoolers were having moderate knowledge on home hazards and their prevention and there is a significant association between knowledge of mothers with educational level and family monthly income of mothers.

The major limitation of the study was that it was conducted on a small sample and hence, the study findings cannot be generalized.

Many implications were drawn out from the study like, nursing curriculum should adequately equip the nursing students with the knowledge on home accidents and the various ways to prevent them, so that they could plan and conduct education sessions for mothers in communities. ASHAs and AWWs play a vital role in health promotional activities. So, an in-service education program can be arranged for them on home accidents and their prevention, thus they will be able to educate mothers regarding this. In area of nursing service, it is an immediate implication for a public health nurse in terms of assessing the areas of poor knowledge in their population and introducing corrective actions to improve the knowledge and practice, thus reducing the incidences of home accidents.

\section{Acknowledgments}

The author would like to place on record the hard work and the tireless efforts in data collection and compilation of the thesis of BSc. Nursing students, Batch 2010-2014 of Teerthankar Mahavir College of Nursing, Moradabad, UP, namely, Ms. Jennifer, Mr. Deepak Kumar, Ms. Harsha Rani, Mr. Hariom, Ms. Farha Khan, and Mr. Harvendra.

\section{Conflict of interest: None}

\section{References}

1. Nanthini Subbiah. Knowledge of mothers on prevention of childhood accidents. The Nursing Journal of India 2006; 229-31.

2. Hossein YE. Effect of mother's education in relation to home accident prevention among preschool children in rural area in El-minia governorate. El-Minia Med Bull 2009; 20(2).

3. Kluwer W. Community Health Nursing, Promoting and Protecting the Public's Health, 4th Edn. Lippincott Williams \& Wilkins 2010; 14: 577-605.

4. Erkal S. Identification of the number of home accidents per year involving children in the $0-6$ age group and the measures taken by mothers to prevent home accidents. Turk J Pediatric 2010; 52: 150-57.

5. Naglaa Saad Abd El-Aty, Moftah FM, HDF I et al. Assessment of knowledge and practice of mothers toward home accidents among children under six years in rural areas in Assiut governorate. Ass Univ Bull Environ Research 2003; 8: 11-29.

6. Oladunjoye GO. Mother's education, age and knowledge about home accident prevention among preschool children in Ilesa Metropolitan city: A relational approach. Journal of Education and Practice 2013; 4(11): 221-27.

Date of Submission: 2017-11-16 Date of Acceptance: 2018-04-09 